\title{
Regulation of MSH Release From the Neurointermediate Lobe of Xenopus laevis by CRF-Like Peptides
}

\author{
B. M. LIDY VERBURG-VAN KEMENADE,* BRUCE G. JENKS, ${ }^{*}$ PETER M. J. M. CRUIJSEN,* \\ ANNELIES DINGS,${ }^{*}$ MARIE-CHRISTINE TONON AND HUBERT VAUDRY \\ *Department of Zoology II, Faculty of Sciences, Catholic University \\ Toernooiveld, 6525 ED Niimegen, The Netherlands \\ Groupe de Recherche en Endocrinologie Moleculaire, UA CNRS 650, Unite Alliee a l'INSERM \\ Faculte des Sciences, Universite de Rouen, 76130 Mont-Saint Aignan, France
}

\author{
Received 12 January 1987
}

\begin{abstract}
VERBURG-VAN KEMENADE, B. M. L., B. G. JENKS, P. M. J. M. CRUIJSEN, A. DINGS, M.-C. TONON AND H. VAUDRY. Regulation of MSH release from the neurointermediate lobe of Xenopus laevis by CRF-like peptides. PEPTIDES 8(6) 1093-1100, 1987.-Immunocy tochemical studies showed the presence of a fiber system containing a CRF-like peptide in the median eminence and in the neural lobe of the pituitary gland of Xenopus laevis. During in vitro superfusion of neurointermediate lobe tissue, CRF, sauvagine and urotensin I induced a rapid and dose-dependent stimulation of secretion of MSH and endorphin. Tissue of white-background adapted animals displayed a remarkably higher sensitivity to CRF and sauvagine than tissue from animals that were adapted to a black background. During superfusion of isolated melanotrope cells in suspension, it was shown that CRF and sauvagine exerted their effect directly on the melanotrope cell. We therefore conclude that there is morphological and biochemical evidence to consider a CRF-like peptide as a physiological MSH-releasing factor.
\end{abstract}

Neurointermediate lobe MSH release CRF Sauvagine Urotensin

CORTICOTROPIN-releasing factor (CRF) is a 41 amino acid peptide [31] which is well-established as potent stimulator of in vivo [27-29] and in vitro [28,36] ACTH secretion from the mammalian anterior pituitary gland. It has been shown that in two non-mammalian vertebrate species, the goldfish [10,11] and the frog Rana ridibunda [34], CRF is also able to stimulate ACTH secretion from corticotrope cells. The proposed neuroendocrine function for this peptide in mammals is supported by its immunocytochemical demonstration in the hypothalamus, median eminence and neural lobe [44]. A similar distribution of immunoreactive material has been shown for lower vertebrate species, including the goldfish and the frog Rana ridibunda $[33,44]$. In this latter species some fibers were also found in the pars intermedia, indicating that a CRF-like peptide could also be involved in the neuroendocrine regulation of the release of $\mathrm{MSH}$ from the intermediate lobe of the pituitary. In this regard, it has been shown for the rat that ovine CRF (o-CRF) is able to stimulate release of $\alpha$-MSH $[2,26,30]$. Bovine intermediate lobe cells could, however, not be stimulated [4]. Despite the positive CRF immunoreaction in the pars intermedia of Rana, the peptide had no effect on the in vitro release of $\alpha$-MSH from the neurointermediate lobe of this species [34].

The non-mammalian peptides, sauvagine and urotensin I, show a remarkable sequence homology with CRF $[8,17,18$, 25]. As many as 20 of the 40 amino acids are found in a homologous region, while 12 other amino acids could be accounted for by a single base-pair change of their genetic code. Urotensin I has been isolated from teleost fish Urophysis and sauvagine from the skin of the South American frog Phylomedusa sauvagea. Sauvagine and urotensin I are potent $\mathrm{ACTH}$ releasing factors in the rat $[6,8,16,28]$. Also, in fish they may stimulate ACTH secretion $[9,10,11$, 17]. Corticotrope and intermediate lobe cells of Rana ridibunda, however, were insensitive to these peptides [34].

In view of the species-specific findings reported above for CRF, we have investigated the involvement of CRF-related peptides in the regulation of secretion from the intermediate lobe melanotropes of Xenopus laevis. The pars intermedia of this amphibian plays an important role in the process of background adaptation, namely the secretion of MSH when the animal is on a black background $[3,5,14]$. It has already been shown that MSH release is controlled by classical neurotransmitters $[21,39,41,43]$ and by peptidergic factors $[38,42]$ of hypothalamic origin.

In our investigation of possible involvement of CRFrelated peptides in the regulation of the pars intermedia of Xenopus laevis, we have (1) determined by immunocytochemistry if there is a morphological basis for regulation through CRF-like peptides, (2) examined the effects of CRF, sauvagine and urotensin I on release of MSH during in vitro superfusion of neurointermediate lobe tissue, and (3) examined the response of isolated melanotropes to 

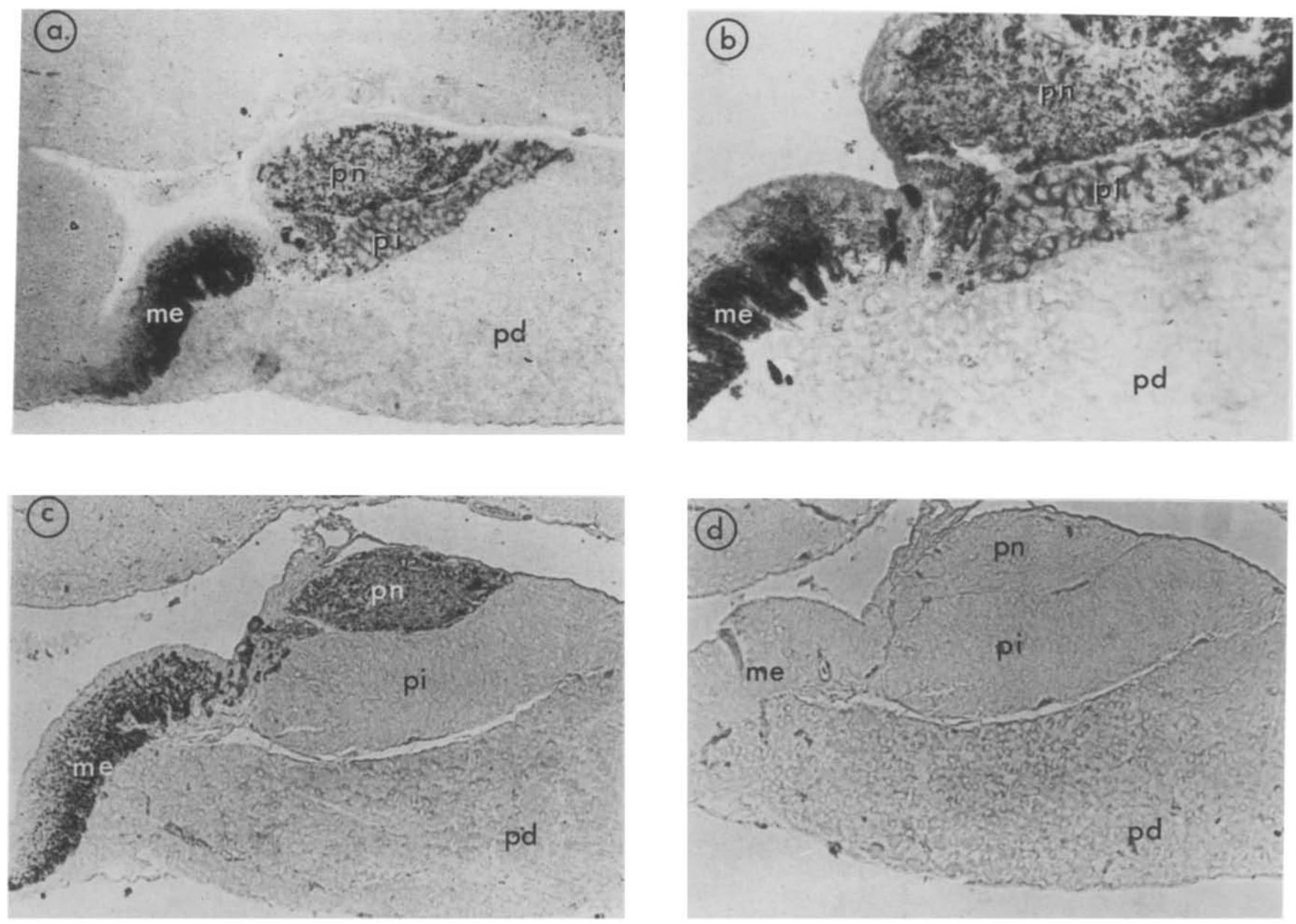

FIG. 1. CRF immunocytochemistry of the pituitary gland of Xenopus laevis, (a) anti-o-CRF staining in pituitary gland and median eminence of a white-background adapted animal shown at $105 \times$ magnification, and (b) shown at $140 \times$ magnification; (c) the anti-CRF staining in the pituitary gland and median eminence of a black-background adapted animal (105 $\times)$; (d) adjacent section after immunoabsorption with o-CRF.

these peptides to determine if they function through direct action on the MSH-cell. $\alpha$-MSH is derived from a large precursor protein, pro-opiomelanocortin (POMC), which in Xenopus melanotrope cells is proteolytically cleaved to form a number of peptides including endorphin $[20,22]$. We therefore extended our analysis to include the effect of CRFrelated peptides in the secretion of immunoreactive endorphin in order to examine the possible occurrence of coordinate or selective regulation of release of POMCderived peptides.

\section{METHOD}

\section{Animals}

Xenopus laevis were bred in our aquatic facility and reared on a grey background. Prior to the experiments, the animals were adapted for at least two weeks to white or black backgrounds at $22^{\circ} \mathrm{C}$ and constant illumination.

\section{Immunocytochemistry With Anti-CRF}

Brain and pituitary tissue were fixed in Bouin-Hollande, paraplast embedded, and $5 \mu \mathrm{m}$ sections were immunostained overnight at $4^{\circ} \mathrm{C}$ with the peroxidase-anti-peroxidase method according to Sternberger [32] using $4 \mathrm{Cl}$-naphtol as oxygen acceptor. The C-terminally directed antiserum (code $\mathrm{Cl} 24$ ), dilution 1:150, was raised against o-CRF and was provided by Dr. L. Linton (Redding, England). In radioimmunoassays the antibody did not show cross-reactivity with sauvagine or urotensin [19]. Control experiments were performed after adsorption of the antiserum with o-CRF or sauvagine.

\section{In vitro Superfusion of Neurointermediate Lobe Tissue}

Our superfusion system contains four independent superfusion chambers (10 $\mu \mathrm{l}$ volume each). A single neurointermediate lobe was placed in each chamber and incubation medium (112 mM NaCl, $2 \mathrm{mM} \mathrm{KCl}, 2 \mathrm{mM} \mathrm{CaCl}, 15 \mathrm{mM}$ Hepes pH 7.38, 0.3 mg/ml BSA, $2 \mathrm{mg} / \mathrm{ml}$ glucose and carbogen aerated) was pumped through the chambers at a rate of $1.5 \mathrm{ml} / \mathrm{hr}$ at $22^{\circ} \mathrm{C}$. Fractions of $7.5 \mathrm{~min}$ were collected and stored at $-20^{\circ} \mathrm{C}$ until submission to radioimmunoassay for MSH or endorphin. After a $1 \mathrm{hr}$ equilibration period a superfusion medium was given which contained o-CRF, sauvagine or urotensin. After a 15 min pulse the system was switched again to standard incubation medium. Maximum superfusion time was $6 \mathrm{hr}$ during which a maximum of four pulses of neuropeptide could be given. Results of separate experiments are expressed as a percentage of basal secretion; $100 \%$ basal secretion is defined as the average MSH or endorphin value that was measured during the $15 \mathrm{~min}$ before se- 


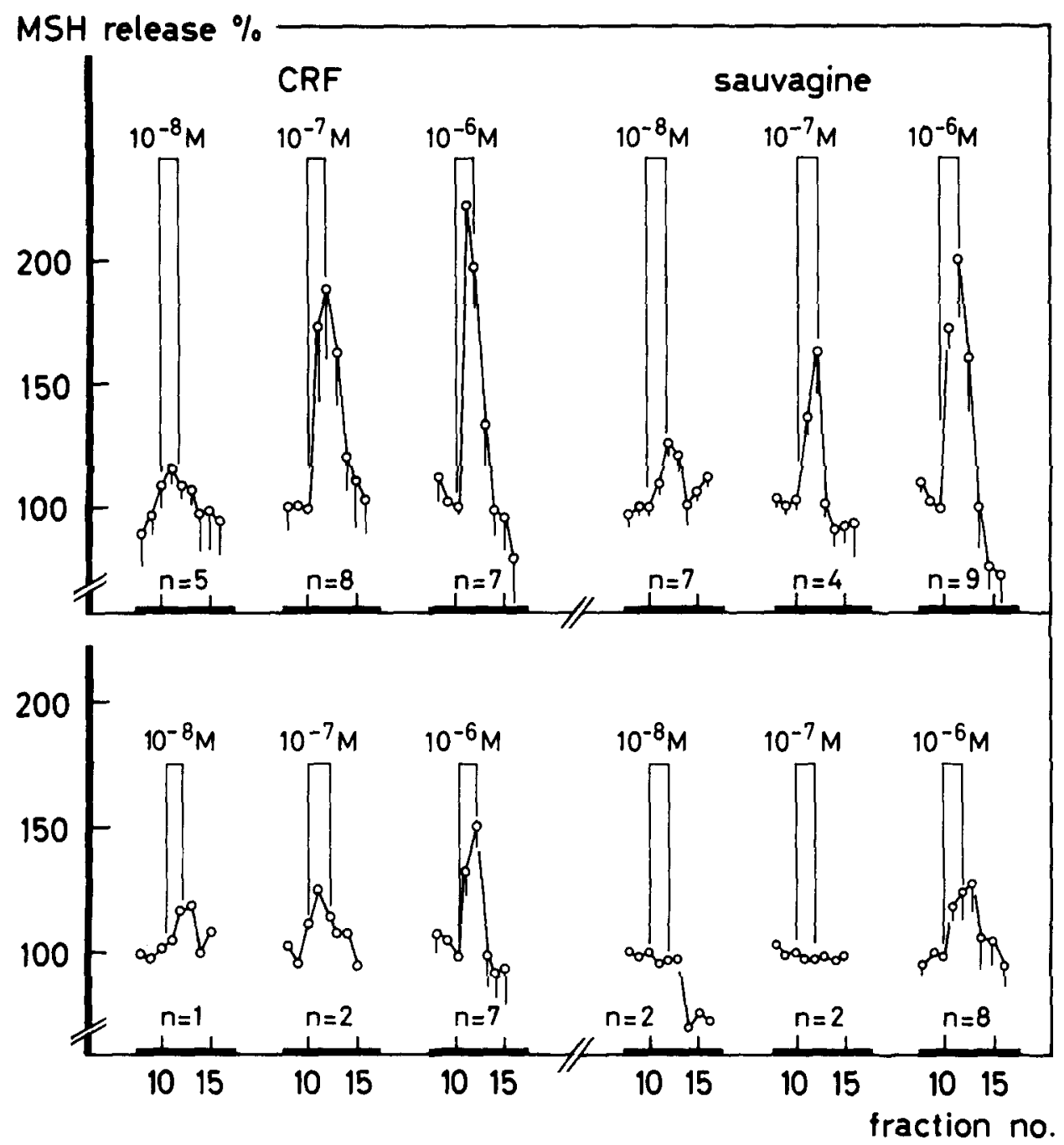

FIG. 2. Effect of CRF $\left(10^{-8}, 10^{-7}, 10^{-6} \mathrm{M}\right)$ or sauvagine $\left(10^{-8}, 10^{-7}, 10^{-6} \mathrm{M}\right)$ on $\mathrm{MSH}$ secretion during in vitro superfusion of neurointermediate lobes of white- (top profiles) and of black-background (bottom profiles) adapted animals. Neuropeptides were administered during $15 \mathrm{~min}$ periods as indicated in the figure. Each figure represents the average of several individual lobes $(n=$ number of lobes). The $100 \%$ values of basal secretion were defined from the average MSH secretion during $15 \mathrm{~min}$ before the administration of secretagogues. These values were for lobes of white-background adapted animals, CRF $10^{-8} \mathrm{M}: 1012 \mathrm{pg} / 7.5 \mathrm{~min}, 10^{-7} \mathrm{M}: 1878 \mathrm{pg} / 7.5 \mathrm{~min}, 10^{-6} \mathrm{M}: 1629 \mathrm{pg} / 7.5 \mathrm{~min}$, sauvagine $10^{-8} \mathrm{M}: 960$ $\mathrm{pg} / 7.5 \mathrm{~min}, 10^{-7} \mathrm{M}: 1116 \mathrm{pg} / 7.5 \mathrm{~min}, 10^{-6} \mathrm{M}: 1317 \mathrm{pg} / 7.5 \mathrm{~min}$; for lobes of black-background adapted animals, CRF $10^{-8} \mathrm{M}: 1588 \mathrm{pg} / 7.5 \mathrm{~min}, 10^{-7} \mathrm{M}: 1871 \mathrm{pg} / 7.5 \mathrm{~min}, 10^{-6} \mathrm{M}: 5538 \mathrm{pg} / 7.5 \mathrm{~min}$, sauvagine $10^{-8} \mathrm{M}: 1340 \mathrm{pg} / 7.5 \mathrm{~min}, 10^{-7} \mathrm{M}: 1931 \mathrm{pg} / 7.5 \mathrm{~min}, 10^{-6} \mathrm{M}: 1351 \mathrm{pg} / 7.5 \mathrm{~min}$.

cretagogue addition. Results of the individual lobes were then averaged and SEM values were calculated.

\section{Preparation of Cell Suspensions}

Preparation of cell suspensions and tests concerning cell viability have been published earlier [39]. Neurointermediate lobes were dissected in incubation medium (IM) containing $112 \mathrm{mM} \mathrm{NaCl}, 2 \mathrm{mM} \mathrm{KCl}, 2 \mathrm{mM} \mathrm{CaCl}{ }_{2} \cdot 2 \mathrm{H}_{2} \mathrm{O}, 2 \mathrm{mg} / \mathrm{ml}$ glucose, $15 \mathrm{mM}$ Hepes $\mathrm{pH} 7.38$. The medium was preaerated with carbogen. The tissue was subsequently transferred to $1.5 \mathrm{ml} \mathrm{IM}$ to which was added $3 \mathrm{mg} / \mathrm{ml}$ bovine serum albumin (BSA, Sigma fraction V), $1 \mathrm{mg} / \mathrm{ml}$ collagenase (Sigma) and $1.25 \mathrm{mg} / \mathrm{ml}$ dispase (grade II lyophilisat, Boehringer) and incubated for $1 \mathrm{hr}$ in a shaking waterbath at $22^{\circ} \mathrm{C}$. After centrifugation $\left(10 \mathrm{~min}, 200 \times \mathrm{g}, 22^{\circ} \mathrm{C}\right.$ ) the pellet was carefully sus- pended in $1.5 \mathrm{ml} \mathrm{Ca-free} \mathrm{medium} \mathrm{to} \mathrm{which} 3 \mathrm{mg} / \mathrm{ml} \mathrm{BSA}$ and $0.4 \mathrm{mg} / \mathrm{ml}$ EDTA were added. The suspension was centrifuged, resuspended in $1.5 \mathrm{ml} \mathrm{Ca-free} \mathrm{medium} \mathrm{with} 3 \mathrm{mg} / \mathrm{ml}$ BSA and $1.25 \mathrm{mg} / \mathrm{ml}$ dispase and incubated for $30 \mathrm{~min}$ at $22^{\circ} \mathrm{C}$ with shaking. Tissue fragments were then allowed to settle and the supernatant containing melanotropes in suspension (fraction 1) was saved. The fragments were rinsed and retreated with $\mathrm{Ca}$-free medium containing BSA and dispase, and centrifuged for $3 \mathrm{~min}$ at $200 \times \mathrm{g}$ over a nylon filter (pore size $0.15 \mathrm{~mm}$ ). The collected cell suspension (fraction 2) was combined with fraction 1 and centrifuged $(10 \mathrm{~min} 200 \times$ g). The pellet was rinsed and resuspended in medium containing $3 \mathrm{mg} / \mathrm{ml} \mathrm{BSA}, 0.8 \mathrm{mg} / \mathrm{ml}$ EDTA. Finally it was centrifuged and suspended in incubation medium with $0.3 \mathrm{mg} / \mathrm{ml}$ BSA. All glassware was siliconized. 

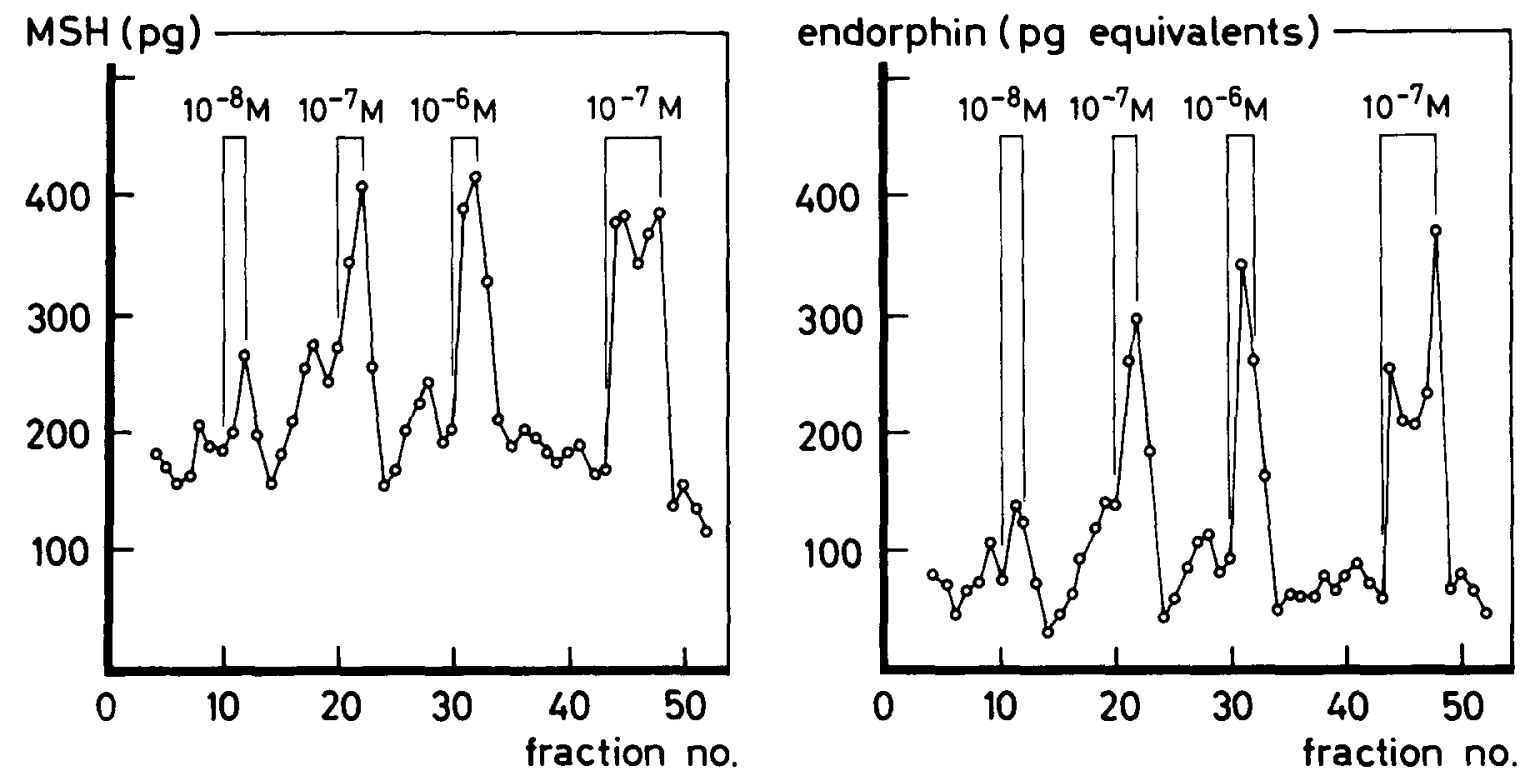

FIG. 3. A comparison of the effect of sauvagine on release of MSH and endorphin from neurointermediate lobe tissue of a white-background adapted Xenopus laevis. Times of sauvagine administration and concentrations used are indicated in the figure.

\section{Superfusion of Isolated Melanotropes}

Cells were suspended in a small volume of incubation medium and loaded in a $50 \mu$ l superfusion chamber with a millipore $0.45 \mu \mathrm{m}$ filter (type HA) at the outlet to support a layer of biogel P2 (Biorad). After loading, the chamber was filled with biogel. Medium was pumped with a peristaltic pump at a rate of $1.5 \mathrm{ml} / \mathrm{hr}$ and $7.5 \mathrm{~min}$ fractions were collected in $100 \mu \mathrm{l}$ ice-cold $0.1 \mathrm{~N} \mathrm{HCl}$. After an equilibration period of approximately $1 \mathrm{hr}$ the effect of neuropeptides was investigated by giving $15 \mathrm{~min}$ pulses of medium containing CRF, sauvagine or TRH. All fractions were stored at $-20^{\circ} \mathrm{C}$ before radioimmunoassay.

\section{Radioimmunoassays}

RIA for $\alpha-M S H$. The C-terminally directed antiserum was characterized earlier [37]. It has equal reactivity to desacetyl- $\alpha$-MSH and $\alpha$-MSH. Immunobound and unbound [125I]MSH were separated either by the use of the second antibody technique or by precipitation with polyethyleneglycol. Sensitivity threshold of the assay is $5 \mathrm{pg}$.

RIA for $\beta$-endorphin. Endorphin was measured with an antiserum produced to porcine endorphin. Characteristics of this antiserum have been published [13]. The antiserum has been used in earlier studies with Xenopus laevis. Dilution curves with Xenopus intermediate lobe extracts and incubation media did not completely parallel those obtained with porcine $\beta$-endorphin (Peninsula Lab Inc., CA). Therefore, within one assay all superfusion fractions were assayed at the same dilution. Thus the results give the relative amount of endorphin released but cannot be considered to be absolute values.

\section{RESULTS}

\section{Immunocytochemistry With Anti-CRF}

Very dense staining with a beaded appearance was visible within the median eminence of black-and white-background
TABLE 1

STIMULATION OF MSH RELEASE BY CRF, SAUVAGINE OR UROTENSIN I, DURING IN VITRO SUPERFUSION OF NEUROINTERMEDIATE LOBES OF BLACK- AND WHITEBACKGROUND ADAPTED Xenopus laevis

\begin{tabular}{|c|c|c|}
\hline & Black & White \\
\hline \multicolumn{3}{|c|}{ CRF } \\
\hline $10^{-8} \mathrm{M}$ & $n=1$ & $116 \pm 7 n=5$ \\
\hline $10^{-7} \mathrm{M}$ & $\mathrm{n}=2$ & $188 \pm 30 n=8$ \\
\hline $10^{-6} \mathrm{M}$ & $152 \pm 9 n=7$ & $222 \pm 27 n=7$ \\
\hline \multicolumn{3}{|c|}{ Sauvagine } \\
\hline $10^{-8} \mathrm{M}$ & $\mathrm{n}=2$ & $126 \pm 5 n=7$ \\
\hline $10^{-7} \mathrm{M}$ & $n=2$ & $162 \pm 16 n=4$ \\
\hline $10^{-6} \mathrm{M}$ & $126 \pm 12 n=8$ & $197 \pm 24 n=9$ \\
\hline \multicolumn{3}{|c|}{ Urotensin I } \\
\hline $10^{-8} \mathrm{M}$ & $130 \pm 7 n=6$ & n.d. \\
\hline $10^{-7} \mathrm{M}$ & $135 \pm 18 n=10$ & $124 \pm 18 n=3$ \\
\hline $10^{-6} \mathrm{M}$ & $156 \pm 10 n=6$ & $141 \quad n=2$ \\
\hline
\end{tabular}

Stimulation of MSH release was calculated in \%. Basal values of release are calculated from the average secretion of MSH during two 7.5 -min fractions just prior to the 15 -min neuropeptide pulse. Percentage of release in top fraction of the pulse is indicated relative to this basal value. Values are given $\pm S E M$. $n=$ number of individual lobes. nd $=$ not determined.

adapted animals (Fig. 1a, b, c). The intermediate lobes of all 6 black-background adapted animals tested were devoid of immunostaining (Fig. 1c). Four out of six intermediate lobes of white-background adapted animals showed a positive immunostaining. This staining was more diffuse than that observed in the neural lobe (Fig. 1a, b). The pars distalis of 


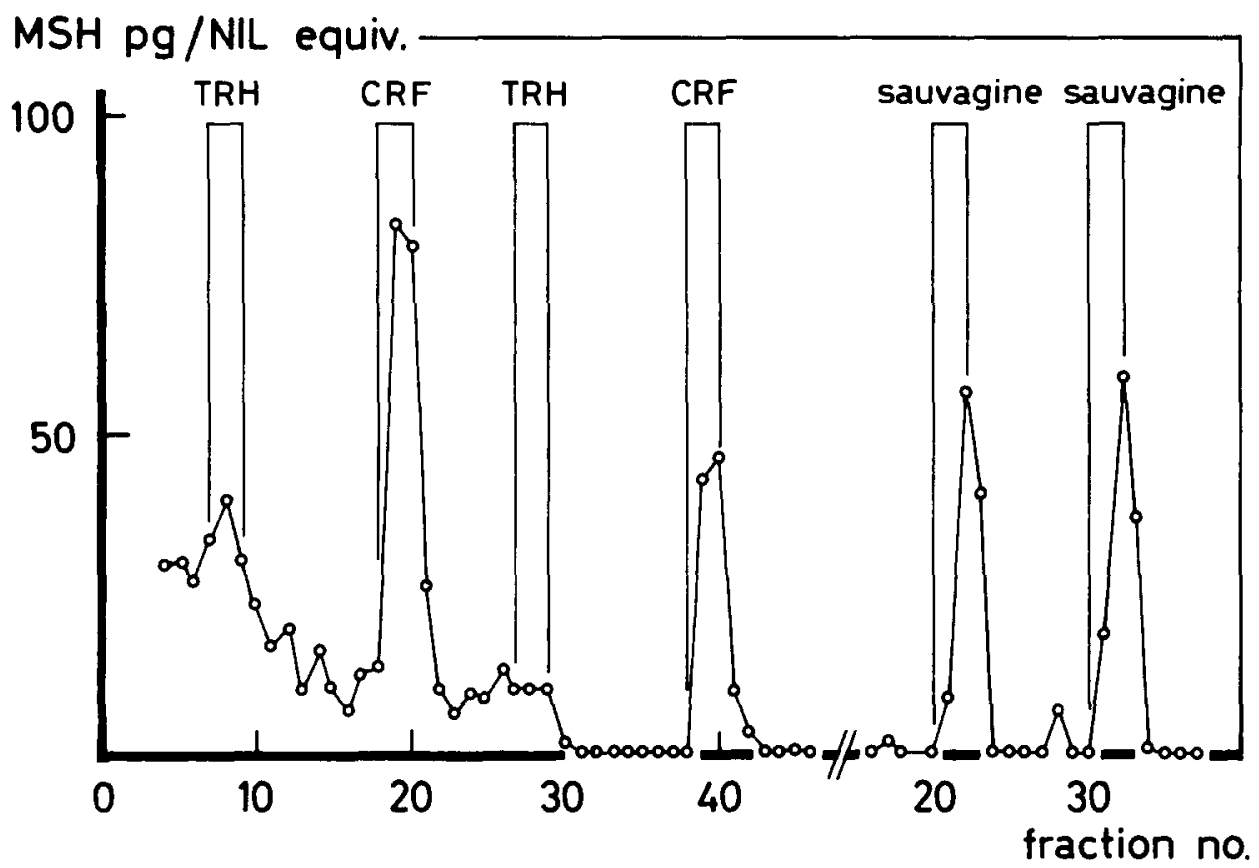

FIG. 4. Effect of TRH $\left(10^{-6} \mathrm{M}\right), \mathrm{CRF}\left(10^{-6} \mathrm{M}\right)$ and sauvagine $\left(10^{-6} \mathrm{M}\right)$ on in vitro secretion of MSH from melanotrope cells isolated from 2 neurointermediate lobes of black-background adapted Xenopus laevis.

black- and white-background adapted animals was devoid of immunostaining. Immunoabsorption with o-CRF eliminated all immunostaining (Fig. 1d). Immunoabsorption with sauvagine was also effective, although a weak reactivity remained in the region of the median eminence (not shown).

Effect of o-CRF, Sauvagine or Urotensin I on Release of MSH and Endorphin During In Vitro Superfusion of Neurointermediate Lobe Tissue

$\mathrm{o}-\mathrm{CRF}$ and sauvagine caused a rapid stimulation of release of MSH from neurointermediate lobe tissue of whitebackground adapted animals (Fig. 2). Lobes from blackbackground adapted animals were less responsive to these neuropeptides, even at $10^{-6} \mathrm{M}$ (Fig. 2, Table 1). The stimulation of secretion from lobes of white-background adapted animals was clearly dose-dependent, in a range of $10^{-8} \mathrm{M}$ to $10^{-6} \mathrm{M}$. The peptide urotensin I stimulated MSH secretion from lobes of black and white animals (Table 1). During in vitro superfusion, the neurointermediate lobe tissue of white-adapted animals showed a decreasing baseline of MSH release, which indicates depletion [41]. Therefore, doserelated responses presented in Table 1 were calculated only from data collected from the first $15 \mathrm{~min}$ pulse of neuropeptide.

Effects of either sauvagine and CRF on release of both endorphin and MSH were measured in media obtained from four superfused lobes. In all cases endorphin and MSH release were concomitantly stimulated. Figure 3 shows an example of analysis of endorphin release after stimulation by sauvagine, together with the results of an analysis of MSH release from the same lobe. In those cases where during superfusion of white-background adapted animals the lobes started to become depleted, the baselines for endorphin release decreased more rapidly than those for release of $\alpha$-MSH.
Effect of CRF, Sauvagine and TRH During In Vitro Superfusion of Isolated Melanotrope Cells

CRF, sauvagine or TRH were administered during superfusion of melanotrope cells isolated from neurointermediate lobe tissue of black-background adapted animals. In Fig. 4 it is shown that the cells remain insensitive to TRH. However, sauvagine and CRF clearly induced the release of MSH from these cells. Experiments with TRH and sauvagine were repeated and gave similar results to those illustrated. Also two experiments with urotensin I showed that these cells are also responsive to this neuropeptide.

\section{DISCUSSION}

The immunocytochemical staining in nerve terminals in the median eminence and neurohypophysis indicate that a CRF-like peptide could be involved in the control of pituitary function in Xenopus laevis. From the very dense staining found in the median eminence we conclude that in this species a CRF-like peptide will likely reach the anterior pituitary via the portal system, possibly to regulate secretion of ACTH. In addition many axons run into the pars nervosa and thus a CRF-like peptide might ultimately reach the pars intermedia, either by direct innervation or by diffusion from the neural lobe. The anti-CRF staining in the pars intermedia was rather diffuse and not of the beaded nature expected of nerve fibers. This might argue for diffuse delivery of a CRFlike peptide from the neural lobe, although a thorough morphological study is necessary to confirm this. The fact that immunostaining in the pars intermedia, when observed, was restricted to white-adapted animals might indicate that in the living animal the neuropeptide is released only in this physiological state, possibly in the regulation of low basal secretion from melanotrope cells.

Our immunocytochemical results indicate a morphological basis for the regulation of the pars intermedia through 
peptides structurally related to mammalian CRF. Nothing has been reported about the structure of endogenous CRF or sauvagine-like molecules in Xenopus laevis, and thus we are unable to comment on the precise nature of this immunostaining. Although the ovine CRF antiserum used in the present study does not cross-react with synthetic sauvagine in radioimmunoassay procedures [19], in our histochemical procedure sauvagine was quite effective in absorbing the antiserum.

Results of superfusion experiments with neurointermediate lobes show that o-CRF, sauvagine and urotensin I stimulate MSH secretion. An interesting phenomenon in this regard is the difference in the response to these peptides between lobes from black- and white-background adapted animals. Tissue from white-background adapted animals shows a higher response to sauvagine and CRF, a phenomenon noted earlier for TRH-induced stimulation of secretion from intact neurointermediate lobes [42]. The observation that immunocytochemical staining of CRF-like material within the pars intermedia was restricted to white-adapted animals might suggest that the CRF-like peptides are only functional in white-adapted animals. The fact that these peptides were effective in stimulating MSH release from isolated melanotrope cells shows that these neuropeptides exert their effect directly on the MSH cells, rather than indirectly such as effecting release of other regulatory factors within the neurointermediate lobe tissue.

A possible explanation for the different response of tissue from black- and white-background adapted animals could be a ligand-induced desensitization of receptors during adaptation to black background. This supposition, however, is not supported by our immunocytochemical results, which indicated the presence of a CRF-like peptide in the intermediate lobe of white-adapted animals only. Another possibility is that the difference in response is related to a difference in intracellular mechanisms utilized by these peptides in stimulus-secretion coupling. For the pars intermedia of the rat it has been established that CRF concomitantly stimulates release of $\alpha$-MSH and intracellular accumulation of cyclic AMP (cAMP) $[15,24]$. We have previously shown that cAMP is involved as second messenger in the regulation of MSH secretion from Xenopus melanotropes [40,41]. Interestingly, there is parallelism in the response of Xenopus melanotropes to the CRF-like peptides and to the cAMP analogues. As with the CRF-like peptides, 8-Br-cAMP is effective in stimulating MSH secretion from neurointermediate lobe tissue of white-adapted animals, whereas lobes of black-background adapted animals show a poor response. Both CRF-like peptides and 8-Br-cAMP stimulate secretion of MSH from isolated melanotrope cells from blackbackground adapted animals. We have previously suggested that the endogenous cAMP concentration in melanotropes of black-background adapted animals is at a level which gives maximum responses and that this level drops during the $6 \mathrm{hr}$ preparation of the cell suspension under release inhibited conditions $[40,41]$. This would render the cells sensitive to
cAMP and to secretagogues that function through the adenylate cyclase system. Our present finding that isolated melanotropes are almost completely insensitive to TRH might suggest that if this neuropeptide acts directly on the melanotrope cells, it may not do so through activation of the adenylate cyclase system. In studies with $\mathrm{GH}_{3}$ cells TRH has been shown to work through mobilization of calcium $[12,23]$. An alternative explanation is that TRH effects secretion of MSH in Xenopus through an indirect mechanism.

POMC processing results in the formation of a number of secretory peptides and in previous biosynthetic studies we have examined whether or not secretagogues cause a coordinate release of newly synthesized radioactive peptides. These studies have shown that the inhibitory factors dopamine [21, 35, 39], GABA [1,43], and NPY [7,38] induce coordinate inhibition. The low biosynthetic activity of the pars intermedia of white-background adapted animals [14,45] prohibits extension of this analysis to the stimulatory neuropeptides. One of the important POMC-derived peptides is endorphin. Secretion of endorphin from Xenopus neurointermediate lobes can be analyzed with a radioimmunoassay to $\beta$-endorphin $[38,43]$. Using this assay GABAand NPY-induced inhibition of immunoreactive endorphin was established. The present results show that there is a coordinate stimulation of endorphin and MSH secretion by CRF and sauvagine.

Our results suggest that the pars intermedia of Xenopus laevis is under dual regulation which involves not only the well established inhibitory mechanisms but also stimulatory neuropeptides. Many of the inhibitory factors have been shown to work directly on the melantrope cells, an observation which is now extended to the stimulatory action of the CRF-related peptides. Therefore, the neuroendocrine regulation of the pars intermedia seems to be very complex, with the melanotropic cell itself acting as a centre of integration for the hypothalamic input. Such complexity is surprising in view of the fact that the functioning of the pas intermedia of amphibians is at first glance rather simple: production and secretion of MSH in animals on black background, storage of the peptide in animals on a white background. In evaluating the possible significance of this complex system, one should also consider the possibility that regulation of the dermal melanophores could involve not only input concerning the color of background but also other parameters such as temperature, stress and temporal factors. Unfortunately, little is known concerning the physiological functioning of dermal melanophores, other than during background adaptations.

\section{ACKNOWLEDGEMENTS}

The authors want to thank Dr. Liz Linton, Redding, U.K., for kindly supplying the anti-CRF, and Drs. Ling, Lederis and Rivier respectively for the kind supply of CRF, urotensin I and sauvagine. We thank Mr. T. Coenen and Mr. A. G. J. Driessen for technical assistance and Mrs. E. M. Jansen-Hoorweg for typing the manuscript. This work was supported by E. E. C. grant No. STI-084-5C.

\section{REFERENCES}

1. Adjeroud, S., M. C. Tonon, M. Lamacz, E. Leneveu, M. E. Stoeckel, M. L. Tappaz, L. Cazin, J. M. Danger, C. Bernard and $H$. Vaudry. GABA-ergic control of $\alpha$-melanocyte-stimulatinghormone $(\alpha-\mathrm{MSH})$ release by frog neurointermediate lobe in vitro. Brain Res Bull 17: 717-723, 1986
2. Al-Noaemi, M. C., J. A. Edwardson and D. Hughes. Corticotropin-releasing factor (CRF) stimulates release of peptides from the intermediate lobe of the rat pituitary gland. $J$ Physiol 332: 85, 1982. 
3. Bagnara, J. T. and M. E. Hadley. Chromatophores and Color Change: The Comparative Physiology of Animal Pigmentation. Englewood Cliffs, NJ: Prentice Hall, 1973.

4. Baird, A., W. B. Wehrenberg, T. Shibasaki, R. Benoit, Z. Chong-Li, F. Esch and N. Ling. Ovine corticotropin-releasing factor stimulates the concomitant secretion of corticotropin, $\beta$-lipotropin, $\beta$-endorphin and $\alpha$-melanotropin by the bovine adenohypophysis in vitro. Biochem Biophys Res Commun 108: 859-864, 1982.

5. Bower, A., M. E. Hadley and V. J. Hruby. Biogenic amines and control of MSH-release. Science 184: 70-72, 1974.

6. Brown, M. R., L. A. Fischer, J. Spiess, J. Rivier, C. Rivier and W. Vale. Comparison of the biologic actions of corticotropin releasing factor and sauvagine. Regul Pept 4: 107-114, 1982.

7. Danger, J. M., F. Leboulenger, J. Guy, M. C. Tonon, M. Benyamina, J-C. Martel, S. Saint-Pierre, G. Pelletier and H. Vaudry. Neuropeptide $\mathrm{Y}$ in the intermediate lobe of the frog pituitary acts as an $\alpha$-MSH-release inhibiting factor. Life $S \subset i$ 39: 1183-1192, 1986.

8. Erspamer, V. and P. Melchiorri. Actions of amphibian skin peptides on the central nervous system and anterior pituitary. In: Neuroendocrine Perspectives, Vol. 2, edited by E. E. Mueller and R. M. MacLeod. Amsterdam: Elsevier, 1983, pp. 37106.

9. Fryer, J., K. Lederis and J. Rivier. Urotensin I, a CRF-like neuropeptide, stimulates ACTH release from teleost pituitary. Endocrinology 113: 2308-2310, 1983.

10. Fryer, J., K. Lederis and J. Rivier. Cortisol inhibits the ACTHreleasing activity of urotensin $\mathrm{I}, \mathrm{CRF}$ and sauvagin observed with superfused goldfish pituitary cells. Peptides 5: 925-930, 1984.

11. Fryer, J., K. Lederis and J. Rivier. ACTH-releasing activity of urotensin I and ovine CRF: Interactions with arginine vasotocin, isotocin and arginine vasopressin. Regul Pept 11: 11-16, 1985.

12. Gershengorn, M. C. and C. Thaw. Thyrotropin-releasinghormone (TRH) stimulates biphasic elevation of cytoplasmic free calcium in GH3 cells. Further evidence that TRH mobilizes cellular and extracellular $\mathrm{Ca}^{2+}$. Endocrinology 116: 591-596, 1985.

13. Jegou, S., M. C. Tonon, P. Leroux, F. Delarue, G. Leboulenger, G. Pelletier, J. Cote, N. Ling and H. Vaudry. Immunological characterization of endorphins, adrenocorticotrophin and melanotropins in frog hypothalamus. Gen Comp Endocrinol 51: 246-254, 1983.

14. Jenks, B. G., A. P. van Overbeeke and B. F. McStay. Synthesis, storage and release of MSH in the pars intermedia of the pituitary gland of Xenopus laevis during black adaptation. Can J Zool 55: 922-927, 1977.

15. Labrie, F., B. Gagne, G. Lefevre and M. Meunier. CRF stimulates adenylate cyclase activity in the intermediate lobe of the pituitary gland. Mol Cell Endocrinol 30: 347-351, 1983.

16. Lederis, $K$. The fish urotensins: hypophyseal and peripheral actions in fishes and mammals. In: Frontiers in Neuroendocrinology, edited by L. Martini and W. F. Ganong. New York: Raven Press, 1984, pp. 246-263.

17. Lederis, K., A. Letter, D. McMaster, G. Moore and D. Schlesinger. Complete amino acid sequence of urotensin $\mathrm{I}$, a hypotensive and corticotropin-releasing neuropeptide from $\mathrm{Cus}$ tomus. Science 218: 162-164, 1982.

18. Lederis, K., W. Vale, J. Rivier, K. L. MacCannel, D. McMaster, Y. Kobayashi, U. Suess and J. Laurence. Urotensin I. A novel CRF-like peptide in Catostomus commersoni. Proc West Pharmacol Soc 25: 223-227, 1982.

19. Linton, E. A., G. E. Gillies and P. J. Lowry. Ovine corticotropin-releasing factor and vasopressin: antibodyquenching studies on hypothalamic extracts of normal and brattleboro rats. Endocrinology 113: 1878-1882, 1983.
20. Martens, G. J. M., B. G. Jenks and A. P. van Overbeeke. Analysis of peptide biosynthesis in the neurointermediate lobe of Xenopus laevis using high-performance liquid chromatography: occurrence of small bioactive products. Comp Biochem Physiol 67B: 493-497, 1980.

21. Martens, G. J. M., B. G. Jenks and A. P. van Overbeeke. Microsuperfusion of neurointermediate lobes of Xenopus laevis: Concomitant and coordinately controlled release of newly synthesized peptides. Comp Biochem Physiol 60C: 75-82, 1981.

22. Martens, G. J. M., B. G. Jenks and A. P. van Overbeeke. Biosynthesis of pairs of peptides related to melanotropin, corticotropin and endorphin in the pars intermedia of the amphibian pituitary gland. Eur J Biochem 122: 1-10, 1982.

23. Martin, T. F. J. and J. A. Kowalchyk. Evidence for the role of calcium and diacylglycerol as dual second messengers in thyrotropin-releasing hormone action: Involvement of diacylglycerol. Endocrinology 115: 1517-1526, 1984.

24. Meunier, H., G. Lefevre, D. Dumont and F. Labrie. CRF stimulates $\alpha$-MSH secretion and cyclic AMP accumulation in rat pars intermedia cells. Life Sci 31: 2129-2136, 1982.

25. Montecucchi, P. C. and A. Henschen. Amino acid composition and sequence analysis of sauvagine, a new active peptide from the skin of Phyllomedusa sauvagei. Int J Protein Res 18: 113120, 1981.

26. Proux-Ferland, L., F. Labrie, D. Dumont, J. Cote, D. H. Coy and J. Sveiraf. Corticotropin-releasing factor stimulates secretion of melanocyte-stimulating hormone from the rat pituitary. Science 217: 62-63, 1982.

27. Rivier, C., M. Brownstein, J. Spiess, J. Rivier and W. Vale. In vivo corticotropin-releasing factor-induced secretion of adrenocorticotropin, $\beta$-endorphin and corticosterone. Endocrinology 110: 272-278, 1982.

28. Rivier, C., J. Rivier, K. Lederis and W. Vale. In vitro and in vivo ACTH-releasing activity of ovine CRF, sauvagine and urotensin I. Regul Pept 5: 139-143, 1983.

29. Rivier, C. and W. Vale. Modulation of stress-induced ACTH release by corticotropin-releasing factor, catecholamines and vasopressin. Nature 305: 325-327, 1983.

30. Sakly, M., G. Schmitt and B. Koch. CRF enhances release of both $\alpha-\mathrm{MSH}$ and ACTH from anterior and intermediate pituitary. Neuroendocrinol Lett 4: 289-293, 1982.

31. Spiess, J., J. Rivier and W. Vale. Primary structure of corticotropin-releasing factor from ovine hypothalamus. Proc Natl Acad Sci USA 78: 6517-6521, 1981.

32. Sternberger, L. A. Immunocytochemistry, 2nd ed. New York: Wiley, 1979

33. Tonon, M. C., A. Burlet, M. Lauber, P. Cuet, S, Jegou, L. Gouteux, N. Ling and H. Vaudry. Immunohistochemical localization and radioimmunoassay of corticotropin-releasing factor in the forebrain and hypophysis of the frog Rana ridibunda. Neuroendocrinology 40: 109-119, 1985.

34. Tonon, M. C., P. Cuet, M. Lamacz, S. Jegou, J. Cote, L. Gouteux, N. Ling, G. Pelletier and H. Vaudry. Comparative effects of corticotropin-releasing factor, arginine vasopressin, and related neuropeptides on the secretion of ACTH and $\alpha$-MSH by frog anterior pituitary cells and neurointermediate lobes in vitro. Gen Comp Endocrinol 61: 438-445, 1986.

35. Tonon, M. C., P. Leroux, M. E. Stoeckel, S. Jegou, G. Pelletier and H. Vaudry. Catecholaminergic control of $\alpha$ melanocyte-stimulating hormone $(\alpha-\mathrm{MSH})$ release by frog neurointermediate lobe in vitro: Evidence for a direct stimulation of $\alpha$-MSH release by thyrotropin-releasing hormone. Endocrinology 112: 133-141, 1983.

36. Vale, W., J. Spiess, C. Rivier and J. Rivier. Characterization of a 41-residue ovine hypothalamic peptide that stimulates secretion of corticotropin and $\beta$-endorphin. Science 213: 1394-1397, 1981.

37. Vaudry, H., M. C. Tonon, C. Delarue, R. Vaillant and J. Kraicer. Biological and radioimmunological evidence for melanocyte stimulating hormones (MSH) of extrapituitary origin in the rat brain. Neuroendocrinology 27: 9-24, 1978. 
38. Verburg-van Kemenade, B. M. L., B. G. Jenks, J. M. Danger, H. Vaudry, G. Pelletier and S. Saint-Pierre. An NPY-like peptide may function as MSH-release inhibiting factor in Xenopus laevis. Peptides 8: 61-67, 1987.

39. Verburg-van Kemenade, B. M. L., B. G. Jenks and A. G. J. Driessen. GABA and dopamine act directly on melanotropes of Xenopus laevis to inhibit MSH secretion. Brain Res Bull 17: 697-704, 1986.

40. Verburg-van Kemenade, B. M. L., B. G. Jenks and A. J. H. M. Houben. Regulation of cyclic-AMP synthesis: in amphibian melanotrope cells through catecholamine and GABA receptors. Life Sci 40: 1859-1867, 1987.

41. Verburg-van Kemenade, B. M. L., B. G. Jenks and A. P. van Overbeeke. Regulation of melanotropin release from the pars intermedia of the amphibian Xenopus laevis: evaluation of the involvement of serotonergic, cholinergic, or adrenergic receptor mechanisms. Gen Comp Endocrinol 63: 471-480, 1986.
42. Verburg-van Kemenade, B. M. L., B. G. Jenks, Th. Visser, M. C. Tonon and H. Vaudry. Assessment of TRH as a potential MSH release stimulating factor in Xenopus laevis. Peptides 8: 69-76, 1987.

43. Verburg-van Kemenade, B. M. L., M. Tappaz, L. Paut and B. G. Jenks. GABAergic regulation of melanocyte-stimulating hormone reaction from the pars intermedia of Xenopus laevis: immunocytochemical and physiological evidence. Endocrinology 118: 260-267, 1986.

44. Verhaert, P., S. Manivolt, F. Vandesande and A. Deloof. Localization of CRF immunoreactivity in the central nervous system of three vertebrate and one insect species. Cell Tissue Res 238: 49-53, 1984.

45. Weatherhead, B. and P. Whur. Quantification of the ultrastructural changes in the "melanocyte stimulating hormone cell" of the pars intermedia of the pituitary in the amphibian Xenopus laevis after change of background color. $J$ Endocrinol 51: 521$532,1972$. 